\title{
A MULHER NEGRA NO CONTO "MARIA" DE CONCEIÇÃO EVARISTO: LÉXICO, AVALIATIVIDADE E REPRESENTAÇÃO DISCURSIVA
}

\author{
Ana Maria Azevedo de Oliveira ${ }^{1}$ \\ Dina Maria Martins Ferreira ${ }^{2}$ \\ Ingrid Xavier dos Santos ${ }^{3}$ \\ Isabela Feitosa Lima Garcia ${ }^{4}$
}

\begin{abstract}
Resumo
O presente trabalho objetiva analisar a mulher negra considerando o cenário social brasileiro, via literatura, cujo gênero discursivo pode provocar intervenções na maneira como determinado grupo é apresentado no meio social e representado discursivamente, ou seja, grupos pertencentes a minorias marginalizadas - população negra, indígenas, mulheres, pessoas com deficiências, assalariados, classe pobre, etc. Analisamos o conto Maria de Conceição Evaristo na obra Olhos d'água (2016), uma espécie de registro social feito por quem vivenciou situações semelhantes, seja na própria pele, seja no grupo de convivência, pois oferece um panorama sobre a forma como são perpetuadas, no discurso, as visões estereotipadas da sociedade em relação às pessoas que vivem na periferia das cidades e lutam diariamente para romper as barreiras da fome, da miséria, bem como as atitudinais que estão incrementadas por olhares preconceituosos. Para a constituição da análise abordamos as categorias léxico (ABBADE, 2016, BIDERMAN, 2001, GAMA; QUEIROZ, 2012), avaliatividade (VIANA JR., 2009, MARTIN; WHITE, 2005) e representação discursiva direcionada à constituição da identidade e da diferença (HALL, 2006, GIDDENS, 2002, SILVA, 2012), que inferem e constroem o engessamento representacional da mulher negra, sem chance a um outro lugar.
\end{abstract}

Palavras-chave: Mulher negra. Léxico. Avaliatividade. Representação Discursiva.

\section{THE BLACK WOMAN IN THE SHORT STORY "MARIA” BY CONCEIÇÃO EVARISTO: LEXICON, EVALUATIVENESS AND DISCURSIVE REPRESENTATION}

\begin{abstract}
The present work aims at analyzing the black woman considering the Brazilian social scenario, through literature, which discursive genre can provoke interventions in the way a certain group is presented in the social environment, and also discursively represented, that is, groups belonging to marginalized minorities - black population, indigenous people, women, people with disabilities, wage earners, urban poor, etc. We analyse the short story Maria by Conceição Evaristo from her novel Olhos d'Agua (2016), which is a kind of social record made by those

\footnotetext{
1 Universidade Estadual do Ceará. Mestranda pelo Programa de Pós-Graduação em Linguística Aplicada da Universidade Estadual do Ceará. ORCID http://orcid.org/0000-0001-9101-1271. E-mail: aninha.azevedo@aluno.uece.br.

2 Universidade Estadual do Ceará. Pós-doutora e professora do Programa de Pós-Graduação em Linguística Aplicada da Universidade Estadual do Ceará. ORCID http://orcid.org/0000-0003-2585-497X. E-mail: dinaferreira@terra.com.br.

${ }^{3}$ Universidade Estadual do Ceará. Doutoranda pelo Programa de Pós-Graduação em Linguística Aplicada da Universidade Estadual do Ceará. ORCID http://orcid.org/0000-0002-5660-6007. E-mail: ingridxaviersantos@yahoo.com.br.

${ }^{4}$ Universidade Estadual do Ceará. Doutoranda pelo Programa de Pós-Graduação em Linguística Aplicada da Universidade Estadual do Ceará. ORCID http://orcid.org/0000-0001-7643-2318. E-mail: isabela.garcia@aluno.uece.br.
} 
who experienced similar situations, either individually or in their social group, as it provides an overview of how stereotyped views of society are perpetuated in the discourse in relation to people who live on the edges of towns and struggle daily to break the barriers of hunger, misery, as well as attitudinal barriers that are increased by prejudiced eyes. For the constitution of the analysis we approach the lexical categories (ABBADE, 2016, BIDERMAN, 2001, GAMA; QUEIROZ, 2012), evaluativeness (VIANA JR., 2009, MARTIN; WHITE, 2005) and discursive representation aimed at the constitution of identity and difference (HALL, 2006, GIDDENS, 2002, SILVA, 2012), who infer and build the representational crystallized of the black woman, without chance to other place.

Keywords: Black Woman. Lexicon. Evaluativeness. Discursive Representation.

\section{INTRODUÇÃO}

Ser mulher em uma sociedade que demonstra, a cada dia, por meio de suas práticas sociais, o quanto a misoginia está calcificada em seu cerne é tarefa árdua. Todavia, ser mulher negra e moradora de periferia parece ser uma luta de sobrevivência diária, porquanto são corpos marcados pela violência e pelo desrespeito, cotidianamente feridos não apenas por marcas físicas de abuso, mas também por discursos gerados por ideologias dominantes e por estruturas hegemônicas que coisificam e subalternizam os corpos das mulheres, em especial os das mulheres negras.

Nessa seara, a escritora Conceição Evaristo, na obra Olhos d'água (2016), traz uma ontologia de 15 contos que narram de modo assertivo a difícil e segregante realidade de pessoas que moram nas periferias. Dentre essas pessoas, moradores de comunidades - morros e favelas -, o olhar da autora rascunha a vida das mulheres que vivem nessas regiões marginalizadas. Mulheres essas, que são marcadas por representações sociais e discursivas que já existiam muito antes delas nascerem, e por conseguinte, mulheres sem direito à defesa e à voz, que não só morrem em becos, em pontos de ônibus e são linchadas não somente por paus, pedras e chutes, mas também por discursos que delimitam quem são sujeitos agentes e não-agentes a partir de marcas estereotipadas.

Ante essa realidade cruel e misógina, consideramos a literatura, em especial a afrobrasileira, a que apresenta um levante crítico mediante as práticas abusivas que a sociedade comete contra à comunidade negra. Deste modo, este artigo tem como objetivo discutir como são construídas as representações discursivas identitárias (HALL 2006, GIDDENS,2002, SILVA, 2012) da mulher negra, moradora de periferia e mãe solo, no conto Maria, a partir das categorias de léxico (ABBADE, 2016; BIDERMAN, 2001; GAMA; QUEIROZ, 2012), e da Teoria da Avaliatividade (VIANA JR., 2009; MARTIN; WHITE, 2005). 
A escolha/da seleção deste conto deu-se pela escolha lexical de cunho avaliativo, bem como pela organização dos enunciados feitos pela autora, - que, por sua vez, constrói uma esquematização texto-discursiva -, que espelha o preconceito arraigado no processo de interação verbal.

Isso posto, este artigo está dividido em dois eixos principais: no primeiro, abordamos o referencial contextual, no qual inicialmente lançamos mão acerca do discurso literário e um breve histórico sobre a autora Conceição Evaristo; em seguida, fazemos uma abordagem teórica de como o léxico é constitutivo de avaliatividade, que nos leva tanto à representação discursiva identitária da mulher negra, e quanto à diferença de raça vista pela sociedade hegemônica.

\section{DISCURSO LITERÁRIO E CONCEIÇÃO EVARISTO}

\subsection{DISCURSO LITERÁRIO}

O conceito de literatura tem sido discutido por muitos estudiosos durante bastante tempo, ou seja, o que é literatura, o que torna um texto literário ou não, quais os elementos intrínsecos ao texto literário. Tais indagações nos levam a perceber que o discurso literário diverge de outros tipos de discursos, como o político e o jornalístico, por exemplo, pois, para muitos, o discurso literário se alimenta de uma complexidade constitutiva:

\footnotetext{
A experiência literária não só nos permite saber da vida por meio da experiência do outro, como também vivenciar essa experiência. Ou seja, a ficção feita palavra na narrativa e a palavra feita matéria na poesia são processos formativos tanto da linguagem quanto do leitor e do escritor. Uma e outra permitem que se diga o que não sabemos expressar e nos falam de maneira mais precisa o que queremos dizer ao mundo, assim como nos dizer a nós mesmos (COSSON, 2018, p. 17).
}

Além das peculiaridades que o discurso literário apresenta, muito se discute sobre o poder e as vantagens que a leitura de literatura pode proporcionar. Uma delas, por exemplo, é a visão mais abrangente do mundo que o leitor adquire a partir do ato da leitura. De um lado, podemos dizer que um leitor literário compreende melhor a realidade e mostra-se hábil na busca por mudanças políticas e sociais, entre outros aspectos relacionados à vida em sociedade. Por outro, no entanto, não se pode afirmar que a leitura de textos literários seja a salvação/solução para todos os males da humanidade.

O que é dito é que a literatura tem um papel de grande importância na formação do homem, pois é a partir desta, que se faz possível obter informações em relação a inúmeros contextos e áreas do conhecimento, contribuindo assim para a formação cultural e pessoal do indivíduo. Sobre a humanização a partir da literatura de Candido (2017), este autor afirma que 
"Ela não corrompe nem edifica, portanto; mas, trazendo livremente em si o que chamamos o bem e o que chamamos o mal, humaniza em sentido profundo, porque faz viver". (CANDIDO, 2017, p. 85). É a partir do contato e da leitura de textos literários que será possível ao homem conhecer outros mundos, sejam imaginários, sejam baseados na realidade.

Considerando essas possibilidades que o texto literário apresenta, focamos nosso olhar na luta da mulher, em geral e principalmente negra, no decorrer da história, uma vez que percebemos grandes avanços no meio social através de diferentes lutas, quase sempre ressignificadas por homens, de forma arbitrária e desumana. Assim, a voz da mulher, considerada 'um ser em construção', continua silenciada em meio às anulações e às desigualdades que sempre atormentam a sua perseverante existência enquanto sujeito construtor da própria identidade, do próprio corpo, das próprias vontades e escolhas, de suas peculiares necessidades, que vão para além do fisiológico.

Testemunhamos essa voz que (não-)ecoa, apesar de tudo o que já fora registrado por meio de relatos, seja na literatura e/ou por outros meios, divulgados ou não, originária do feminino presente em uma carcaça considerada humana de acordo com a legislação vigente, que anseia incessantemente pela simplória continuidade de viver, de lutar incansavelmente para o trato com respeito - necessidades que a possibilite exercer livremente a sua cidadania, que tanto lutou para desfrutar, mesmo quando, em alguns contextos, seja considerada um simples vocábulo sem acepção, uma espécie de nomenclatura fictícia e difícil de ser associada à vida inteligente no planeta.

\subsection{CONCEIÇÃO EVARISTO}

Diante desse cenário de construção intelectual, tanto a escritora quanto a figura feminina têm insistido em permanecer presente e atuante, mesmo diante dos preconceitos ainda em vigor. Um bom exemplo disso é a originalidade posta por Conceição Evaristo diante de um acervo literário que apresenta a representatividade da mulher negra em um país historicamente permeado por racismo, machismo e inúmeras formas de preconceito. Esta autora traz à tona questões sociais que pairam sobre as populações menos favorecidas do nosso país, tomando como assertiva a figura da mulher, em especial a mulher negra. Trata-se de uma contribuição à literatura, à história e à sociedade assinalada pelo próprio percurso de vida da autora, cujo discurso literário foi constituído por motivações e por indagações factuais, arraigadas a demandas inerentes a sujeitos como ela, coabitantes de desigualdades e de situações de 
violências (física, moral, atitudinal etc.), que podem ser vistas com os olhos da transformação social e política e da sensibilidade humana.

O fato de pertencer a uma família com muitos filhos e poucos recursos não tornou Conceição Evaristo menos relutante diante dos desafios que a sociedade da época propunha. Para isso, a escritora mineira, além de enfrentar as diversas situações de preconceitos surgidas no dia a dia, agregou os estudos à rotina de empregada doméstica em prol de construir uma vida mais digna. Com 25 anos de idade mudou-se para o Rio de Janeiro, onde cursou a Faculdade de Letras pela Universidade Federal do Rio de Janeiro (UFRJ), tornou-se mestra em Literatura Brasileira pela Pontifícia Universidade Católica do Rio de Janeiro (PUC-Rio) e doutora em Literatura Comparada pela Universidade Federal Fluminense (UFF).

A partir dessas significativas escolhas e realizações, a autora começou a construir seu próprio caminho rumo à visibilidade literária feminina negra, sendo sua primeira publicação na série Cadernos Negros em 1990, em que aliou literatura à história, por meio da prosa e do 'verso negro', no intuito de desenvolver uma conscientização política, étnica e racial - uma mescla de dores, de emoções, de afetos, de saberes de vivências, que coligada à ficção serviu de inspiração para suas produções literárias. Em 2014 surgiu a coletânea denominada Olhos d'água, uma reunião de 15 contos que evidenciavam, com sutileza e empatia de uma mulher negra, o dia a dia de pessoas femininas que legitimavam as carências de um grupo urbano desprovido de herança, de dinheiro e de espaço para viver dignamente, ou seja, figuras vivas da fome, da miséria, do desemprego, da exclusão social que ainda apresentavam um semblante da 'viuvez' de um futuro mais digno.

\section{CAMINHOS TEÓRICOS}

\subsection{DO LÉXICO À AVALIATIVIDADE}

\subsubsection{Léxico}

Abbade (2016) afirma que "estudar o léxico de uma língua é enveredar pela história, costumes, hábitos e estrutura de um povo, partindo-se de suas lexias. É mergulhar na vida de um povo em um determinado período da história, através do seu léxico.” (ABBADE, 2016, p. 716) Dessa forma, é possível dizer que o léxico é inerente à vida em sociedade, à cultura, ao modo de viver de um povo, uma vez que é construído a partir das interações dos sujeitos em sociedade, nos seus espaços de convivência e em suas áreas de atuação. 


\section{Linguagens - Revista de Letras, Artes e Comunicação - ISSN 1981- 9943 \\ Blumenau, v. 15, n. 2, p. 038-057, maio./ago. 2021.}

A construção lexical de um povo está em constante desenvolvimento e pode ser mudada conforme a necessidade de comunicação, seja no decorrer da história, seja nos registros contemporâneos. Como afirma Biderman (2001, p. 179), “[q]ualquer sistema lexical é a somatória de toda experiência acumulada de uma sociedade e do acervo da sua cultura”.

Onde quer que a língua e as linguagens manifestem-se, o léxico está sendo implantado por meio da recorrência de usos linguísticos significativos de uma determinada comunidade discursiva e independente do espaço geográfico que está inserido. Um exemplo disso são as inúmeras possibilidades de organização lexical presentes na diversidade regional do nosso país, que, apesar de estar atrelada a um idioma oficial, o português brasileiro, apresenta uma riqueza variacional imensurável, demonstrada por meio das peculiaridades de significação próprias de comunidades de fala, idealizadas em diferentes contextos discursivos.

Ao analisarmos o léxico de determinado discurso literário, por exemplo, percebemos a importância da escolha das palavras pelo(a) autor(a) e os significados carregados na palavra escrita. Assim sendo, o léxico faz-se essencial na construção do texto literário, visto que aproxima o cenário ficcional do real, ou melhor, ele

[...] está relacionado a tudo o que os indivíduos inventam, constroem ou consideram relevante, suas crenças, seus interesses e suas atividades. Nesse sentido o léxico de uma língua reflete o modus vivendi de uma dada comunidade, a maneira como seus membros organizam o mundo no qual vivem, bem como estruturam os diferentes aspectos do conhecimento. Assim, ao mesmo tempo em que o léxico recorta realidades de mundo, insere-se na cultura (GAMA; QUEIROZ, 2012, p. 761-762).

Como elemento vivo da língua de um povo e suas manifestações culturais, o léxico ${ }^{1}$ é capaz de constituir-se, reconstituir-se de acordo com a necessidade de entendimento e de comunicação. E como tal, torna-se elemento de estudo nos diversos campos, já que permeia os diferentes discursos vigentes na esfera social e resulta de relações que permeiam as linguagens e a língua.

\subsubsection{Avaliatividade}

Estudar o léxico em diferentes discursos contribui também para entender sua atuação na construção do sistema de avaliatividade. Esse é um sistema linguístico-discursivo que segundo Viana (2016, p.100) "possibilita ao leitor perceber estratégias, empregadas por autores de um texto, de avaliação de comportamento do "outro"” (aspas simples do original).

\footnotetext{
${ }^{1}$ As nomenclaturas teóricas estarão em itálico em determinados momentos para auxiliar a leitura e a análise
} 


\title{
Linguagens - Revista de Letras, Artes e Comunicação - ISSN 1981- 9943 \\ Blumenau, v. 15, n. 2, p. 038-057, maio./ago. 2021.
}

Esse sistema foi proposto por Martin e White (2005) que o entendem como uma 'fotografia linguística', que possibilita mensurar o comportamento do 'outro' em meio às relações de poder. A avaliatividade está diretamente embasada em uma relação intrinsecamente dialógica, em que linguagem e contexto estão diametralmente relacionados. Viana Jr (2009, p. 107) assevera que

\begin{abstract}
A relação entre linguagem e contexto e as possibilidades de avaliações que podem ser feitas pelos usuários nos contextos em que interagem faz emergir o Sistema de Avaliatividade como um sistema de recursos interpessoais à disposição do produtor de textos para que se posicione em relação ao que expressa. E aqui a palavra SISTEMA é de suma importância, não se tratando de uma teoria, mas um conjunto, um sistema de opções em nível semântico discursivo à disposição dos usuários que, no nível léxico-gramatical, será instanciado em um texto pelos mecanismos linguísticos de avaliação dos quais a língua dispõe.
\end{abstract}

Viana Jr (2009) ainda afirma que a avaliatividade trata de um sistema interpessoal no âmbito da semântica do discurso, que, por sua vez, está subdividido em três subsistemas: atitude, gradação e envolvimento.

As atitudes estão ligadas às características semânticas relacionadas ao afeto, aos juízos de valores (julgamentos) e às valorações ou apreciações que se almeja transmitir.

No que tange à gradação dentro do discurso, essa diz respeito ao foco e à força que se deseja transmitir. Exemplo para elucidar as duas subcategorias: Ele é negro, mora na periferia, é ladrão. O foco, ou seja, o objetivo do enunciado é explicar por que uma determinada pessoa negra é ladra. Tal perspectiva é acentuada ( $f \circ r c ̧ a$ ) pelo uso dos verbos no presente do indicativo, pelas vírgulas e pela força do campo semântico socialmente estabelecido para naturalizar que pessoas negras, moradoras de periferias são ladras.

Por fim, o último subsistema diz respeito ao envolvimento, que Viana Jr (2009) afirma estar relacionado aos aspectos monoglóssicos e heteroglóssicos do discurso. Sobre essas subcategorias é importante compreendê-las dentro do bojo da perspectiva bakhtiniana. Para Bakhtin (2011), a língua, em sua concretude, tem como característica principal ser dialógica. Desse modo, o processo de interação é permeado pela linguagem e embebido de relações dialógicas, que são as relações de sentido presentes nos enunciados produzidos pelos locutores. Esses enunciados são formados por inúmeros fios dialógicos que trazem consigo as vozes de diversos sujeitos sociais, podendo ser concordantes ou dissonantes.

À vista disso, os aspectos heteroglóssicos do discurso dizem respeito às vozes produzidas por diversos sujeitos sociais, em que cada enunciado traz consigo inúmeras outras marcas embutidas, além da voz do emissor. Todavia, é válido ressaltar que as relações 
dialógicas não são amistosas, pois diversas vozes tendem a entrar em conflito, e essas vozes, por sua vez, tentam, de algum modo, cercear o diálogo e monologizar os discursos, ou seja, encerrar o diálogo e dar a palavra final. Assim, no que tange aos aspectos monoglóssicos, esses dizem respeito a vozes sociais equipolentes que tentam cercear os discursos.

Isso posto, apresentamos um esquema a seguir elucidando como o Sistema de Avaliatividade é engendrado:

Figura 01. Sistema de avaliatividade

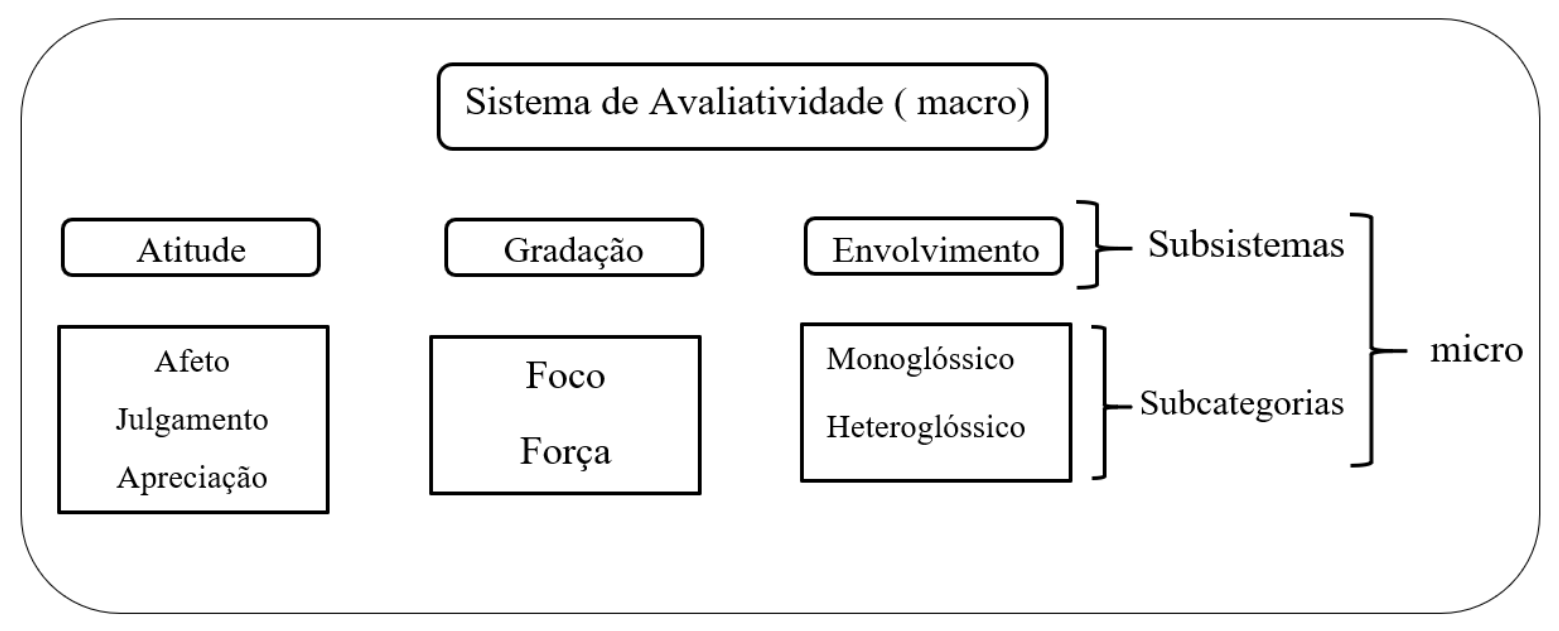

Fonte: Elaborado pelas autoras com base em Viana Jr. (2009)

\subsection{REPRESENTAÇÃO DISCURSIVA}

\subsubsection{Prática social}

Giddens (2002) assevera que o mundo moderno é um mundo em disparada, não somente no sentido em que ocorrem as mudanças sociais, mas também em relação à amplitude e à profundidade em que essas mudanças ocorrem. Tais mudanças são marcadas por uma relação de tempo e espaço que se conectam através da "[...] situacionalidade do lugar" (GIDDENS, 2002, p. 22).

Essa marcação de tempo e espaço na modernidade está tão imbricada na construção das relações sociais que conhecimentos recalcados na mente dos indivíduos, por vezes, podem confundir e demarcar as fronteiras identitárias dos sujeitos. Deslindar as representações discursivas da mulher na pós-modernidade é uma tarefa de reconhecimento de como foi se desenhando a identidade da mulher durante a história das sociedades. É a partir da modernidade que o interesse pela linguagem começa a surgir no âmbito das pesquisas sociais. Segundo Alves e Lira (2018), esse interesse advém da “[...] compreensão de que a linguagem possui importante relação com a vida social. Questões relacionadas a gênero, identidade, [...] passaram a ser 
fortemente relacionadas à linguagem, ao discurso e a outras semioses (ALVES; LIRA, 2018, p.1 05).

A abordagem social proposta por Fairclough (2001) afirma que o discurso é o uso da linguagem como prática social. Ou seja, essa linguagem é tida como modo de ação e nela estão implícitas relações dialéticas entre discurso e estrutura social. Nessa relação, discurso não é uma mera representação do mundo e das coisas, ele se constituiu e constrói-se dentro dessa representação. Assim sendo, Alves e Lira (2018) endossam que a linguagem é uma prática inseparável da vida social. Logo, a Análise de Discurso Crítica (ACD) é um percurso profícuo que "constitui, nessa perspectiva, importante recurso para a análise do processo social, por meio da análise textual" (ALVES; LIRA, 2018, p.106) (itálicos acrescidos).

Fairclough (2001, 2003), a partir da vertente dialético-relacional, vai propor como método analítico para textos a Análise de Discurso Textualmente Orientada (ADTO). De acordo com Magalhães (2004), a ADTO é uma proposta que visa compreender as práticas sociais através de uma égide dialética do discurso em que são observadas tanto os gêneros discursivos como as construções de sentidos produzidas pelo texto - daí o processo de escolha lexical estar ligada à avaliatividade do discurso. Apesar de Fairclough (2001) apresentar em seu arcabouço teórico-metodológico, a construção de sentidos - significado representacional que correspondem ao discurso, o significado acional que corresponde ao gênero discursivo e ao significado identificacional que está atrelado ao estilo -, vamos entender representação discursiva, neste momento, como a construção de sentidos feita a partir da seleção de léxico e respectiva avaliatividade, ou seja, uma forma de delinear os sujeitos desprivilegiados em sua práxis social, que, por sua vez, constrói uma representação discursiva da ordem da identidade e da diferença ${ }^{2}$.

Nessa perspectiva, o texto é entendido como um evento discursivo inserido em um determinado gênero em que "a análise do gênero discursivo se localiza no primeiro estágio de análise: buscar os aspectos semióticos do problema a ser estudado, vinculado às ações das pessoas em práticas sociais" (ALVES; LIRA, 2018, p. 132).

O que está se percebendo, ao utilizarmos o léxico e a avaliatividade é que estamos unindo, de certa forma a Linguística Textual à Análise do Discurso (Adam, 2011). Apesar dessa ligação não vamos nos deter na teoria de Adam (2011) apresentando todos os seus meandros, mas indicando ao leitor a política de seu pensamento. Adam (2011) se apoia em Grize (1996) no que se refere a representação discursiva, ou seja, é

\footnotetext{
${ }^{2}$ Assunto a ser desenvolvimento mais adiante.
} 
uma esquematização tem por função fazer alguém ver alguma coisa, mas precisamente, é uma representação discursiva orientada para um destinatário sobre como seu autor concebe ou imagina uma determinada realidade" (Grize, apud Silva, 2015 , p. 54).

e [isso] significa que o locutor é quem constrói o esquema ou a representação discursiva de acordo com sua visão da realidade remetendo a um locutário. Nesse sentido, o autor considera que, discursivamente, toda esquematização ou representação constrói a imagem do locutor, do alocutário e do tema abordado (QUEIROZ, 2013, p. 224).

Pedimos a Adam (2011), a Grize (1996), a Queiroz (2013) e a Silva (2012) permissão para alocar os locutores no conto Maria, juntando propositadamente os que estão sendo relatados por Conceição Evaristo e os que estão fora do relato, pois todos perfazem a prática social do discurso:

1) Maria (sujeito relatado) e Conceição Evaristo (sujeito relatante) são os locutores da mulher negra - a imagem que fazem de si;

2) Leitores, chofer do ônibus, passageiros do ônibus são os alocutários - ouvem Maria e Conceição Evaristo - a imagem que o locutor faz do alocutário

3) O tema se constrói pelas vozes provocam a criticidade e a mudança social - o conteúdo do texto.

Ratificando nossa proposta, Queiroz (2013, p. 54, aspas do autor) postula que

a representação discursiva do locutor é a "imagem que se faz de si mesmo", a representação discursiva do alocutário é "a imagem que o locutor faz do alocutário" e que "a representação do tema é o conteúdo do texto, as informações elaboradas, veiculadas e interpretadas por um agente locutor e reinterpretadas pelos seus interlocutores."

\subsection{IDENTIDADE E DIFERENÇA}

Quando se fala em identidade, imediatamente relacionamo-na à alteridade. Hall (2006) nos apresenta 3 tipos de identidade, mas só a terceira cabe em nosso estudo. Primeiro, seria uma identidade centrada em si mesmo, que habitou o início do positivismo, apesar de nossa língua ainda mostrar que ela se presentifica. Por exemplo, quando digo "Vou ver o pôr do sol", a minha sensação é ainda de que o sol gira em torno de mim. Esquecemos de Copérnico que há 450 anos nos disse o contrário. Mas a sensação continua a existir talvez porque a Terra também gira em torno de si. Segundo, o sujeito sociológico, já mais complexo, é o sujeito que existiria identitariamente em relação a um outro, mas ainda sem interdependência. É no terceiro que encontramos a identidade ligada à diferença, o sujeito pós-moderno, descentrado, fragmentado, que talvez busque desesperadamente um "essencialismo estratégico" (SPIVAK. 2010). Mas mesmo nesta busca ele não deixa de lado o sofrimento de sua fragmentação, de seu contínuo 
deslocamento. A identidade "parece ser fácil definir 'identidade’. A identidade é simplesmente aquilo que se é: 'sou brasileiro', 'sou negro', 'sou heterossexual', 'sou jovem', 'sou homem' (SILVA, 2012, p. 74, aspas simples do original).

No entanto, identidade e diferença se interligam, haja vista a relação entre o branco hegemônico e a negritude de Maria e Conceição Evaristo. Reproduzindo o pensamento de Miotello e Moura (2013, p. 49), “identidade é o que define o Eu." e "a constituição do Eu sempre é concessão do outro”. (MIOTELLO; MOURA, 2013, p. 50). Afirmações que nos levam a ideia de que o 'eu' negro só existe pelo ‘outro' branco e vice-versa.

Daí podemos dizer que o eu- negro de Maria e de Conceição Evaristo se constituem a partir do mundo exterior, no caso, onde habita o branco. No entanto, esta relação de exclusão pode ser modificada a cada momento de luta por existir, na medida em que

\begin{abstract}
A identidade não se mantém a mesma por toda a vida, ela é mutável e se reconstrói na interação com o outro, consoante se pode confirmar pelas palavras de Cardoso e Sousa (2012, p. 153) ao dizerem que "o discurso é o meio pelo qual o sujeito interage com o outro, avalia a si mesmo e avalia os demais, precipita a pensar de que maneira o outro pensa dele, provocando um processo ininterrupto de construção e reconstrução de identidades". À medida que se identifica com o outro, com sua consciência, com seus valores e suas ideias, a identidade se reconstrói (BEZERRA; QUEIROZ, 2019, p. 226, aspas dos autores).
\end{abstract}

Não foi nesta luta que Conceição Evaristo se colocou junto com Maria? Suas escolhas de léxico com sua avaliatividade não pode ter tocado a "partilha do sensível" (RANCIÈRE, 2020) das humanidades?

\title{
4 O CONTO MARIA
}

Esta seção destina-se à análise do conto Maria, uma das 15 histórias que constituem o livro Olhos D'água (2016), de Conceição Evaristo. Ressaltamos que, nossa análise tem como base o discurso literário, cujo estudo do léxico e avaliatividade vai nos prover a uma visão da representativa identitária do discursivo sobre/de Maria.

Em Olhos D’água (2016), Conceição Evaristo faz um entrelaçar de histórias que envolvem a saudade das percepções, o distanciamento das possibilidades, o sonho de melhorias já inscritas no plano do imaginário, a angústia da multiplicidade da fome, que tanto substância o ser corpóreo, como fomento à luta e até mesmo à serenidade em meio ao possível caos, que aproxima almas e mulheres pela pura ousadia de continuar a viver, a escrever com suor, discernimento e equilíbrio suas histórias. São narrativas de sobrevivência, de otimismo, de amor 


\section{Linguagens - Revista de Letras, Artes e Comunicação - ISSN 1981- 9943 \\ Blumenau, v. 15, n. 2, p. 038-057, maio./ago. 2021.}

fraterno, com filhos, com namorados, com companheiros sem alguma afinidade e/ou parceria, apenas pelo prazer de sentir-se absorvida por alguma forma de contentamento e gozo, com amizades construídas na partilha de situações, choros, angústias e também alegrias na batalha pela dignidade.

Em meio às sutilezas trazidas por Evaristo, encontramos o conto Maria que retrata de forma costumeira o desprestígio do ser mulher, do ser negra, de ter amado ao que infringiu a lei, de estar próximo, mesmo que não participante, mas que aos olhos alheios tornaram-se cúmplices, não do ato em si, mas da cor, da miséria, da fome e da injustiça social. O trato dado a Maria, mãe de filhos órfãos de justiça, de igualdade e muitos outros, demonstra o desrespeito à vida, especificamente por ser uma mulher negra e empregada doméstica, que sustentava honestamente sua prole e costumava pegar a mesma condução para a labuta que escolhera para sobreviver.

No que tange ao léxico, vale ressaltar que Maria é a única personagem do conto que possui nome próprio, pois todas as outras são referidas como o motorista do ônibus, o assaltante, o pai de seu filho, os passageiros, etc. No que concerne à escolha do nome, Conceição Evaristo apresenta-nos à protagonista com um nome comum, conhecido e usado por tantas mulheres (avós, mães, filhas, netas...). A Maria representa tantas 'marias' que sofrem violência todos os dias. Acreditamos que a nominalização de Maria em contrapartida à generalização das outras personagens tem o objetivo de ressaltar a práxis social da mulher negra e sua representação discursiva ${ }^{3}$, sem negar a apreciação negativa de outras personagens cujos papéis sociais se perdem no universo do desprivilegiado.

Quando voltamos o nosso olhar à desigualdade social que assola as mulheres, principalmente a negra, vemos que as possibilidades de acesso ao mercado de trabalho também são injustas e não favorecem sua inserção. Segundo dados da BBC News ${ }^{4}$, de 2018, o Brasil é o país que possui a maior população de domésticas do mundo e grande maioria dessas profissionais é composta por mulheres negras.

Maria, do conto analisado, sofre vários tipos de violência na nossa sociedade. Ela trabalha como empregada doméstica na casa de uma família rica, porém, recebe uma apreciação inferior ao adequado ao seu trabalho. Maria cria seus filhos sozinha, pois foi abandonada pelos pais das crianças e vive com a 'falta de dinheiro', o que a faz viver numa situação (foco) de pobreza extrema, pois sustenta os filhos somente com o que ganha como

\footnotetext{
${ }^{3}$ A ordem de nossa argumentação analítica não obedece necessariamente à ordem teórica do tópico 3 - Caminhos teóricos, na medida em que são os dados que direcionam a argumentação analítica.

${ }^{4}$ Disponível em : <https://www.bbc.com/portugues/brasil-43120953> Acesso em: 04 abr. 2020.
} 
empregada doméstica. Além disso, a protagonista é xingada e espancada no ônibus por conhecer um dos assaltantes, tendo um julgamento sem nenhum direito de defesa. Spivak (2010) afirma que a mudez da mulher subalterna é inquestionável. "Se, no contexto da produção colonial, o sujeito subalterno não tem história e não pode falar, o sujeito subalterno feminino está ainda mais profundamente na obscuridade" (SPIVAK, 2010, p. 85).

A 'Maria' de Conceição Evaristo é a personificação (representação discursiva) dessas mulheres que trabalham como domésticas, mulheres que têm o corpo socialmente e discursivamente demarcado pelas raízes da escravidão e que são subjugadas pela estrutura de força opressora da diferença de classes. Assim, mulheres como Maria, mães solos, que precisam sustentar os seus filhos, necessitam, por vezes, se submeter a elite branca opressora para trazer o sustento para casa. Tais assertivas podem ser aferidas no excerto: No dia anterior, no domingo, havia tido festa na casa da patroa. Ela levava para casa os restos. O osso do pernil e as frutas que tinham enfeitado a mesa. Ganhara as frutas e uma gorjeta. O osso, a patroa ia jogar fora (EVARISTO, 2016, p. 39, itálicos nossos).

Nesse trecho, chamamos atenção para seis itens lexicais que compõem o campo semântico dessa relação opressora entre classes sociais no que tange ao poder aquisitivo entre patrão (força) e empregado: patroa, casa, restos, osso, gorjeta e fora. Através dessas escolhas lexicais, a autora traça estratégias avaliativo-discursivas para apresentar aos leitores o comportamento do 'outro' no patamar do poder. Esse outro, que a autora nos mostra, é um sujeito sem empatia e respeito à necessidade do seu funcionário a ponto de oferecer os restos para a sua funcionária levar para casa e alimentar os seus filhos. Essa construção de sentidos perfila a avaliatividade do subsistema gradação que recebe a subcategoria força sobre o assujeitado, o que não deixa de ser um envolvimento a uma representação discursiva monoglóssica no que tange à valorização hegemônica.

Outro trecho do conto ratifica a subalternidade da mulher na estrutura patriarcal que enreda a vida das mulheres:

Ela teve mais dois filhos, mas não tinha ninguém também. Ficava, apenas de vez em quando, com um ou outro homem. Era tão difícil ficar sozinha! E dessas deitadas repentinas, loucas, surgiram os dois filhos menores. E veja só, homens também! Homens também? Eles haveriam de ter outra vida. Com eles tudo haveria de ser diferente (EVARISTO, 2016, p.40, itálicos nossos).

Nesses enunciados queremos ressaltar os seguintes léxicos: filhos, ninguém, sozinha, deitadas, a locução veja só, homens, outra, vida e diferente. As escolhas lexicais feitas pela autora revelam as atitudes de afeto de e as justifica como necessidade da personagem de buscar 


\section{Linguagens - Revista de Letras, Artes e Comunicação - ISSN 1981- 9943 \\ Blumenau, v. 15, n. 2, p. 038-057, maio./ago. 2021.}

parceiros para ter relações sexuais devido à carência afetiva da personagem. Todavia, as cicatrizes que a personagem carrega das relações patriarcais - atitudes de julgamento - estão dispostas através da gradação da força masculina nos léxicos homens e também, ao trazer ao foco o sentido de patriarcalismo na repetição do léxico homem. E novamente, a autora intervém no envolvimento produzido por um discurso monoglóssico.

O cumprimento ao ex-amante e pai de um dos filhos antes do delito fez parte de uma rememoração de um sentimento não mais latente, embora se fizesse matéria na figura do filho, que fora fruto desse enlace. Com a interrupção da nostalgia pelo anúncio do assalto, em que Maria não foi contemplada, uma vez que se tratava da genitora do filho, a partir de então, começa a dolorosa apreciação àquela mulher: que se outrora sentia a ausência dos carinhos das mãos do homem que amava, e que agora tem seu instinto materno aflorado ao temor de como será a vida de seus filhos: O medo da vida em Maria ia aumentando. Meu Deus, como seria a vida dos seus filhos? Era a primeira vez que ela via um assalto no ônibus (EVARISTO, 2016, p. 43, itálicos nossos).

Nesses enunciados o efeito de gradação no foco da iminência de sua possível morte e da preocupação desta em deixar os seus filhos desamparados. Maria não tem medo da morte, ela tem medo da vida, daquele assalto, in locus, que estava ocorrendo.

Em seguida, Maria foi seguida pela fuga dos assaltantes e pelo ataque à sensibilidade revestida em traços de mulher, que mesmo tentando explicar a não participação no assalto, foi cruelmente xingada, violentada e morta pelos usuários daquele transporte coletivo, em um linchamento que trouxe à tona o preconceito racial, o preconceito de gênero, o preconceito social, que parece intrínseco à formação humana construída desde os tempos mais remotos. Mesmo com a intervenção do motorista, que tenta defendê-la, sem êxito, como percebemos no trecho a seguir:

Calma, pessoal! Que loucura é esta? Eu conheço esta mulher de vista. Todos os dias, mais ou menos neste horário, ela toma o ônibus comigo. Está vindo do trabalho, da luta para sustentar os filhos (EVARISTO, 2016, p. 44, itálico nossos).

Nesse trecho, destacamos os seguintes léxicos: calma, loucura, conheço, de vista, trabalho, sustentar, filhos. A escolha lexical da autora apresenta o apelo do motorista do ônibus aos passageiros enfurecidos. Ele tenta convencê-los de que Maria não tem envolvimento com o assalto, buscando um julgamento para inocentar a protagonista. Mesmo que uma segunda voz entre no discursivo para envolver o leitor para um discurso heteroglóssico, a voz do 'outro' não 
tem uma gradação de força interventora - os passageiros parecem não se importar com o que o homem diz e continuam o espancamento. Com isso, uma possível heteroglossia torna-se uma ilusão, porquanto, naquele espaço de luta, o ônibus, os sujeitos partilham o lugar dos desprivilegiados, inclusive os espancadores, naturalizando o desprestígio da classe trabalhadora que 'pega todos os dias o ônibus para trabalhar' - neste caso é uma monoglossia de uma classe inferior. São sujeitos moldados esteticamente por critérios étnicos, sociais, econômicos, de gênero e opção sexual, no caso, pessoas negras, mulheres, pessoas carentes de recursos financeiros e de escolarização de qualidade, dentre outros. Essa apreciação negativa aos direitos anula a possibilidade de usufruir dos bens coletivos como também da sua própria existência, sem equidade de direitos, de oportunidades, de possibilidades, de visibilidade em todas as esferas sociais, seja de cunho, científico, cultural, artístico, dentre muitos.

Partindo dessa conjectura, inferimos, na narrativa literária de Conceição Evaristo, que as escolhas lexicais, geram um sistema de avaliatividade com o intuito de aproximar o leitor da realidade vigente, no caso a permanente desigualdade social que assola as famílias brasileiras, marcada pela necessidade da mulher de vivenciar condições precárias de acesso ao trabalho -. Assim, veio à tona o preconceito latente, cujas atitudes e gradação sobre o gênero, a cor e a condição social, demonstram a continuidade de aspectos que estigmatizam e rotulam vidas.

A significação dos usos lexicais, negra safada, aquela puta, a negra ainda é atrevida gira em torno do desprestígio do ser humano, gerando afeto à história da protagonista e suscitando no leitor o aparecimento de discursos heteroglóssicos, que vão, na realidade, destoar da realidade discursiva monoglóssica vivenciada pela personagem. Trata-se de uma representatividade discursiva em que as condições (atitudes atribuídas) de ser mulher, negra e empregada doméstica, em relação à gradação de força por parte da sociedade branca, detentora do poder e de um discurso monoglóssico. São atitudes de desvalorização à vida e de descumprimento às leis presentes, embora não vigentes para todos. Não é à toca os gritos de Lincha! Lincha! Lincha! (EVARISTO, 2016, p. 44, itálicos da autora), uma atitude que pôs fim a vida de uma mãe de família que voltava do exaustivo trabalho e, que diante da fatalidade de ter sido amante de um dos assaltantes, tornou-se mais um número diante do extermínio de vidas femininas negras motivadas pelo racismo, pelo machismo e por preconceitos em suas inúmeras faces.

Parece que a identidade constituída pela representatividade discursiva criada por Conceição Evaristo, teve o efeito desejado, - desprivilegiado naturalizado pela força da violência dos próprios desprivilegiados (passageiros do ônibus) e a diferença emerge entre 
privilegiado e desprivilegiado. O foco da denúncia sobre a práxis social vigente, espera-se, atingiu o leitor.

\section{CONSIDERAÇÕES FINAIS}

Em nossas análises, pudemos ratificar o quanto o uso da literatura é um importante instrumento de luta social contra o preconceito. Ademais, observamos que a história de Maria é a narrativa de muitas 'marias' da vida real, 'marias', propositadamente em letras minúsculas por não terem voz, que têm seus corpos estigmatizados e desvalorizados seja pelo descaso governamental com a ausência da garantia dos direitos trabalhistas, seja pela cor da pele que carrega, no imaginário social, as marcas da barbárie que perseveram desde o período da escravidão. Todas essas nuances sociais são materializadas na representação discursiva da mulher negra.

A autora, através de escolhas lexicais, possibilita o leitor compreender as estratégias utilizadas para construir a história de Maria e de tantas outras mulheres negras. Por meio dessas escolhas lexicais forma-se um sistema de avaliatividade em que o comportamento do outro é posto em xeque. Esse outro é a personificação da voz monoglóssica e racista, que escraviza e desrespeita mulheres como Maria.

Essas vozes são materializadas através dos enunciados produzidos pela patroa e pelos passageiros que agridem e lincham Maria, de forma desumana e arbitrária. Isso posto, observamos que o conto traz a representação discursiva de uma mulher que é socialmente marginalizada, desrespeitada e silenciada, seja por agressões físicas e/ou atitudinais que intencionam retirar dela o direito de existir.

Conceição Evaristo incita nos leitores um sentimento de luta em prol do movimento antirracista. Nós leitores precisamos ser a voz heteroglóssica que busca romper as representações discursivas e sociais que estão empoderadas no espaço hegemônico da sociedade. Daí a importância da representatividade dessas minorias nos vários espaços sociais, científicos, intelectuais e financeiros, que estejam engajadas com as causas e as lutas em meio aos desafios surgidos na literatura, no teatro, no jornalismo e nas demais esferas. Enfim, engajamento a processos de reconstrução de atitudes mais humanas que não perpetuem o racismo, o machismo, a homofobia e/ou qualquer forma de preconceito e/ou violência; ações que já vêm sendo colocadas no cerne das discussões de Conceição Evaristo, o que as torna vigentes, atuantes e participantes no processo da humanização social que dá voz também às mulheres negras. 


\section{REFERÊNCIAS}

ABBADE, Celina Márcia de S. Filologia e o estudo do léxico. In: QUEIROZ, Rita de Cássia $\mathrm{R}$ et alii (orgs.) Várias perspectivas dos estudos filológicos. Salvador: Quarteto, 2016.

ADAM, Jean Michel. A Linguística Textual: introdução à análise textual dos discursos. Tradução de Maria das Graças Soares Rodrigues, João Gomes Silva Neto, Luis Passegi e Eulália Vera Lúcia Fraga Leurquin. São Paulo: Cortez, 2011.

ALVES, Regysane B. C.; LIRA, Luciane Cristina E. Teoria social do discurso e evolução da análise do discurso crítica. In: Batista Jr, José R. L; SATO, Denise T.; MELO, Iran F.(orgs). Análise de discurso crítica - para linguistas e não linguistas. São Paulo: Parábola, 2018.

ALMEIDA, Silvio Luiz de. O que é racismo estrutural? Belo Horizonte/MG: Letramento, 2018.

BEZERRA, Jaqueline de J.; QUEIROZ, Maria Eliete. Representação discursiva, identidade e alteridade: entrevista em análise. Verbum, v. 8, n.1, p. 221-235, 2019.

BIDERMAN, Maria Teresa Camargo. Teoria Linguística. 2 ed. Martins Fontes, São Paulo, 2001.

CANDIDO, Antonio. O direito à literatura. In: Vários escritos. 4. ed. São Paulo/Rio de Janeiro: Ouro sobre Azul, 2004.

COSSON, Rildo. Letramento literário: teoria e prática. $2^{\text {a ed., }} 8^{\text {a }}$ reimpressão. São Paulo: Contexto, 2018.

EVARISTO, Conceição. Maria. In: .Olhos d'água. Rio de Janeiro: Pallas: Fundação Biblioteca Nacional, 2016, p. 35-38.

FAIRCLOUGH, Norman. Discurso e mudança social. Brasília: Editora Universidade de Brasília, 2001.

Analyzing Discourse: Textual Analysis for Social Research. UK, Lancaster University Presse, 2003.

GAMA, Vanessa O. S.; QUEIROZ, Rita de Cássia R. de. Léxico e literatura: o vocabulário regional da obra menino de engenho de José Lins do Rego. Cadernos do CNLF, Vol. XVI, n. ${ }^{\circ} 04$, t. 1, 763, 2012.

HALL, Stuart. A identidade cultural na pós-modernidade.16. ed. Tradução Tomaz Tadeu da Silva e Guacira Lopes Louro. São Paulo: DP\&A. 2006

GIDDENS, Anthony. Modernidade e identidade. Rio de Janeiro: Jorge Zahar, 2002.

GRIZE, Jean-Blaise. Logique naturelle \& communications. Paris: P.U.F, 1996.

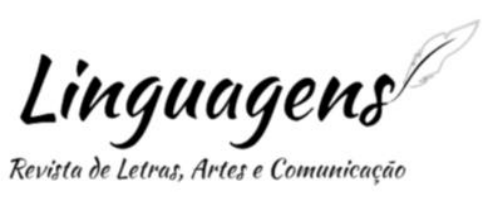


MAGALHÃES, Izabel. Teoria Crítica do Discurso e Texto. Linguagem em (Dis)curso, v.4, p. 113-131, 2004 .

MARTIN, J.R.; WHITE, Peter R.R. The language of evaluation: appraisal in English. New York: Palgrave Macmillan, 2005.

MIOTELLO, Valdemir.; MOURA, M. I. Pensando questões sobre a alteridade e a identidade. In: MIOTELLO, Valdemir.; SCHERMA Camila C.; TURATI, C. (org.). Palavras e contrapalavras: circulando pensares do Círculo de Bakhtin. São Carlos: Pedro \& João Editores, 2013. p. 49-65.

PEREIRA, Amauri M. (Org). O Poder Negro. 2 ed. Belo Horizonte: Nandyala, 2018.

QUEIROZ, Maria. E. Representações discursivas no discurso político. "Não me fiz sigla e legenda por acaso": o discurso de renúncia do senador Antônio Carlos Magalhães (30/05/2001). 2013. 187f. Dissertação (Doutorado em Estudos da Linguagem) - Universidade Federal do Rio Grande do Norte, Natal, 2013.

RANCIÈRE, Jacques. A partilha do sensível: estética e política. Tradução Monica Costa Neto. São Paulo, Editora 34, 2020

SILVA, Tadeu T. A produção social da identidade e da diferença. In: SILVA, Tadeu. T. (org.). Identidade e diferença: a perspectiva dos estudos culturais. 11. ed. Petrópolis, Rio de Janeiro: Vozes, 2012.

SPIVAK, Gayatri Chakravorty. Pode o subalterno falar? Tradução. Sandra Regina Goulart Almeida; Marcos Pereira Feitosa; André Pereira. Belo Horizonte: Editora da UFMG, 2010.

VIANA, Karina M. N. Representações linguístico-discursivas de mulheres gestantes em situação prisional: uma análise de discursos crítica. 2016. 390 f. Tese (Doutorado em Linguística), Universidade de Brasília, Brasília, 2016.

VIANA JR, Orlando. O sistema de avaliatividade e os recursos para gradação em Língua Portuguesa: questões terminológicas e de instanciação. DELTA: Documentação de Estudos em Lingüística Teórica e Aplicada, v. 25, n. 1, p. 99-129, 2009.

\section{ANEXO - Maria}

Maria estava parada há mais de meia hora no ponto do ônibus. Estava cansada de esperar. Se a distância fosse menor, teria ido a pé. Era preciso mesmo ir se acostumando com a caminhada. O preço da passagem estava aumentando tanto! Além do cansaço, a sacola estava pesada. No dia anterior, no domingo, havia tido festa na casa da patroa. Ela levava para casa os restos. $\mathrm{O}$ osso do pernil e as frutas que tinham enfeitado a mesa. Ganhara as frutas e uma gorjeta. O osso, a patroa ia jogar fora. Estava feliz, apesar do cansaço. A gorjeta chegara numa hora boa. Os dois filhos menores estavam muito gripados. Precisava comprar xarope e aquele remedinho de desentupir nariz. Daria para comprar também uma lata de Toddy. As frutas estavam ótimas e havia melão. As crianças nunca tinham comido melão. Será que os meninos iriam gostar de 
melão? A palma de uma de suas mãos doía. Tinha sofrido um corte, bem no meio, enquanto cortava o pernil para a patroa. Que coisa! Faca a laser corta até a vida! Quando o ônibus apontou lá na esquina, Maria abaixou o corpo, pegando a sacola que estava no chão entre as suas pernas. O ônibus não estava cheio, havia lugares. Ela poderia descansar um pouco, cochilar até a hora da descida. Ao entrar, um homem levantou lá de trás, do último banco, fazendo um sinal para o trocador. Passou em silêncio, pagando a passagem dele e de Maria. Ela reconheceu o homem. Quanto tempo, que saudades! Como era difícil continuar a vida sem ele. Maria sentou-se na frente. O homem sentou-se a seu lado. Ela se lembrou do passado. Do homem deitado com ela. Da vida dos dois no barraco. Dos primeiros enjoos. Da barriga enorme que todos diziam gêmeos, e da alegria dele. Que bom! Nasceu! Era um menino! E haveria de se tornar um homem. Maria viu, sem olhar, que era o pai de seu filho. Ele continuava o mesmo. Bonito, grande, o olhar assustado não se fixando em nada e em ninguém. Sentiu uma mágoa imensa. Por que não podia ser de uma outra forma? Por que não podiam ser felizes? E o menino, Maria? Como vai o menino? cochichou o homem. Sabe que sinto falta de vocês? Tenho um buraco no peito, tamanha a saudade! Tou sozinho! Não arrumei, não quis mais ninguém. Você já teve outros... outros filhos? A mulher baixou os olhos como que pedindo perdão. É. Ela teve mais dois filhos, mas não tinha ninguém também. Ficava, apenas de vez em quando, com um ou outro homem. Era tão difícil ficar sozinha! E dessas deitadas repentinas, loucas, surgiram os dois filhos menores. E veja só, homens também! Homens também? Eles haveriam de ter outra vida. Com eles tudo haveria de ser diferente. Maria, não te esqueci! Tá tudo aqui no buraco do peito... O homem falava, mas continuava estático, preso, fixo no banco. Cochichava com Maria as palavras, sem entretanto virar para o lado dela. Ela sabia o que o homem dizia. Ele estava dizendo de dor, de prazer, de alegria, de filho, de vida, de morte, de despedida. Do buraco - saudade no peito dele... Desta vez ele cochichou um pouquinho mais alto. Ela, ainda sem ouvir direito, adivinhou a fala dele: um abraço, um beijo, um carinho no filho. E logo após, levantou rápido sacando a arma. Outro lá atrás gritou que era um assalto. Maria estava com muito medo. Não dos assaltantes. Não da morte. Sim da vida. Tinha três filhos. O mais velho, com onze anos, era filho daquele homem que estava ali na frente com uma arma na mão. O de lá de trás vinha recolhendo tudo. O motorista seguia a viagem. Havia o silêncio de todos no ônibus. Apenas a voz do outro se ouvia pedindo aos passageiros que entregassem tudo rapidamente. $\mathrm{O}$ medo da vida em Maria ia aumentando. Meu Deus, como seria a vida dos seus filhos? Era a primeira vez que ela via um assalto no ônibus. Imaginava o terror das pessoas. O comparsa de seu ex-homem passou por ela e não pediu nada. Se fossem outros os assaltantes? Ela teria para dar uma sacola de frutas, um osso de pernil e uma gorjeta de mil cruzeiros. Não tinha relógio algum no braço. Nas mãos nenhum anel ou aliança. Aliás, nas mãos tinha sim! Tinha um profundo corte feito com faca a laser que parecia cortar até a vida. Os assaltantes desceram rápido. Maria olhou saudosa e desesperada para o primeiro. Foi quando uma voz acordou a coragem dos demais. Alguém gritou que aquela puta safada lá da frente conhecia os assaltantes. Maria se assustou. Ela não conhecia assaltante algum. Conhecia o pai de seu primeiro filho. Conhecia homem

que tinha sido dela e que ela ainda amava tanto. Ouviu uma voz: Negra safada, vai ver que estava de coleio com os dois. Outra voz vinda lá do fundo do ônibus acrescentou: Calma, gente! Se e la estivesse junto com eles, teria descido também. Alguém argumentou que ela não tinha desci 
do só para disfarçar. Estava mesmo com os ladrões. Foi a única a não ser assal- tada. Mentira, eu não fui e não sei porquê. Maria olhou na direção de onde vinha a voz e viu um rapazinho negro e magro, com feições de menino e que relembravam vagamente o seu filho. Primeira voz, a que acordou a coragem de todos, tornouse um grito: Aquela puta, aquela negra safada estava com os ladrões! O dono da voz levantou e se encaminhou em direção à Maria. A mulher teve medo e raiva. Que merda! Não conhecia assaltante algum. Não devia satisfação a ninguém. Olha só, a negra ainda é atrevida, disse o homem, lascando um tapa no rosto da mul her. Alguém gritou: Lincha! Lincha! Lincha!... Uns passageiros desceram e outros voaram em direção à Maria. $\mathrm{O}$ motorista tinha parado o ônibus para defender a passageira: - Calma pessoal! Que loucura é esta? Eu conheço esta mulher de

vista. Todos os dias, mais ou menos neste horário, ela toma o ônibus comigo. Está vindo do trabalho, da luta para sustentar os filhos...

Lincha! Lincha! Lincha! Maria punha sangue pela boca, pelo nariz e pelos ouvidos. A sacola havia arrebentado e as frutas rolavam pelo chão. Será que os meninos iriam gostar de melão? Tudo foi tão rápido, tão breve, Maria tinha saudades de seu ex-homem. Por que estavam fazendo isto com ela? O homem havia segredado um abraço, um beijo, um carinho no filho. Ela precisava chegar em casa para transmitir o recado. Estavam todos armados com facas a laser que cortam até a vida. Quando o ônibus esvaziou, quando chegou a polícia, o corpo da mulher estava todo dilacerado, todo pisoteado. Maria queria tanto dizer ao filho que o pai havia mandado um abraço, um beijo, um carinho.

Submetido: $18 / 03 / 2021$

Aceito: 07/12/2021 